\title{
Effect of Sulphur Fertilization in Combinition of Farmyard Manure on Sesame (Sesamum indicum L.)
}

\author{
K. Mamatha ${ }^{1 *}$, G.E.Ch. Vidya Sagar ${ }^{1}$, P. Laxmi Narayana ${ }^{1}$ and G. Padmaja ${ }^{2}$ \\ ${ }^{1}$ Department of Agronomy, College of Agriculture, Professor Jayashankar Telangana State \\ Agricultural University, Rajendranagar, Hyderabad - 500 030, Telangana, India \\ ${ }^{2}$ Department of Soil Science \& Agricultural Chemistry, College of Agriculture, Professor \\ Jayashankar Telangana State Agricultural University, Rajendranagar, Hyderabad - 500 030, \\ Telangana, India \\ *Corresponding author
}

\begin{tabular}{|c|c|}
\hline & A B S T R A C T \\
\hline $\begin{array}{l}\text { Sesame, Sulphur, } \\
\text { Farmyard manure. }\end{array}$ & \multirow{3}{*}{ 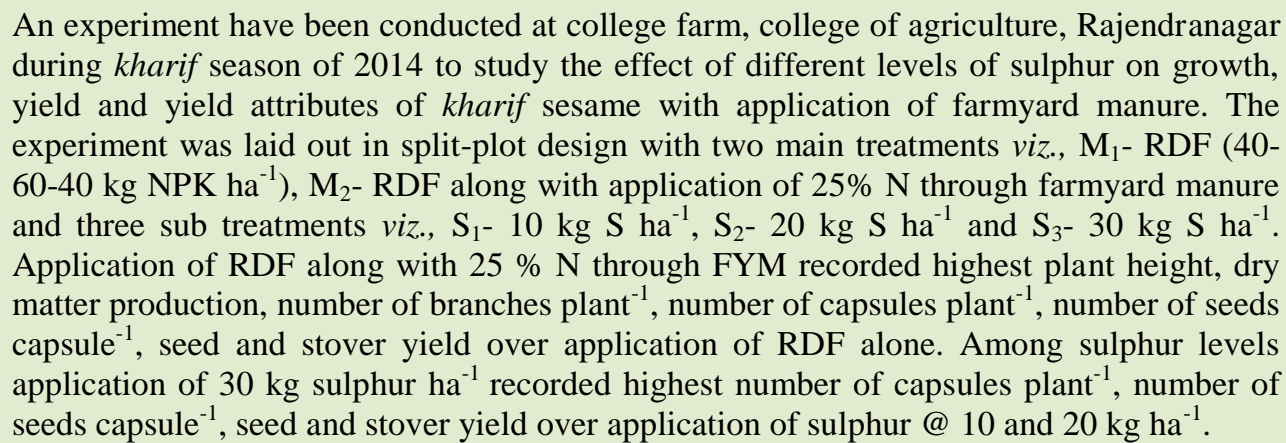 } \\
\hline Article Info & \\
\hline $\begin{array}{l}\text { Accepted: } \\
\text { 10 July } 2017 \\
\text { Available Online: } \\
\text { 10 September } 2017\end{array}$ & \\
\hline
\end{tabular}

\section{Introduction}

Sesame (Sesamum indicum L.) is one of the most important oil seed crops belongs to Pedaliaceae family and extensively grown in different parts of the world and it ranks fourth among oil seed crops in the world. Sesame occupies 19.42 lakh hectares area with production and productivity of $0.58 \mathrm{mt}$ and $303 \mathrm{~kg} \mathrm{ha}^{-1}$ respectively during 2013 constituting 6.1 per cent and 2.8 per cent of area and production of total oilseeds in India (Indiastat.com). Telangana accounts for 0.24 lack hectares with production and productivity of 0.09 lakh tonnes and $360 \mathrm{~kg}$ $\mathrm{ha}^{-1}$ respectively.
Sesame is drought resistant crop, which can be easily grown under rainfed conditions and it has been grown all over the world for thousands of years and said to be ancient crop in India. Sesame is a versatile crop with high quality edible oil having diversified usage. Sesame contains $4655 \%$ oil, $20-25 \%$ protein also contains vitamins, amino acids and polyunsaturated fatty acids. Sesame can play an important role to fulfill the local demand of edible oil. As sesame is short duration and photo insensitive crop with wider adaptability, it can be cultivated throughout the year. 
In view of population growth, the requirement of edible oil is increasing day by day. It is therefore highly expected that the production of edible oil should be increased considerably to fulfill the increasing demand. The production may be increased by increasing the area under oil seed crop or increasing yield per unit area. But in the present condition scope of expansion of oilseeds is narrow. So, there is consensus that increasing yield vertically is more reasonable way to increase total production.

Prolonged use of chemical fertilizers alone in intensive cropping systems leads to unfavourable soil fertility, harmful effects on soil physico-chemical and biological properties and undermine sustainable crop production. Deficit of organic matter makes the situation worst for oil seed crops. The fact that crop deficiencies of sulphur have been reported with increase in frequency over the past several years' greater attention has been focused on the importance of sulphur in plant nutrition (Scherer, 2001).

\section{Materials and Methods}

The present experiment on sesame was conducted during kharif 2014 at College Farm, College of Agriculture, Rajendranagar, Professor Jayashankar Telangana State Agricultural University, Rajendranagar, Hyderabad. The soil of the experimental site was sandy loam in texture with $\mathrm{pH}$ of 7.9, electrical conductivity $0.41 \mathrm{dSm}^{-1}$, low in organic carbon $(0.40 \%)$, available nitrogen $\left(175 \mathrm{~kg} \mathrm{ha}{ }^{-1}\right)$, medium in available phosphorus $\left(36 \mathrm{~kg} \mathrm{ha}^{-1}\right)$ and high in available potassium $\left(342 \mathrm{~kg} \mathrm{ha}^{-1}\right)$ and low in available sulphur $\left(19.7 \mathrm{~kg} \mathrm{ha}^{-1}\right)$. The experiment was laid out side by side in a split-plot design with 6 treatments comprised of two main plot treatments i.e., $\mathrm{M}_{1}$ - Recommended Dose of Fertilizer and $\mathrm{M}_{2}-$ Recommended Dose of Fertilizer along with $25 \% \mathrm{~N}$ through farm yard manure with three sub-plot treatments in each experiment i.e. three sulphur levels (10 $\mathrm{kg} \mathrm{ha}^{-1}, 20 \mathrm{~kg} \mathrm{ha}^{-1}$ and $30 \mathrm{~kg} \mathrm{ha}^{-1}$ ) replicated four times. Full dose of $\mathrm{P}_{2} \mathrm{O}_{5}$ and $\mathrm{K}_{2} \mathrm{O}$ along with half of the nitrogen in all the treatments was applied as basal. Remaining nitrogen was applied at 30 DAS.

\section{Results and Discussion}

\section{Plant height}

Persual of the data on plant height revealed that application of RDF along with application of $25 \% \mathrm{~N}$ through farmyard manure recorded significantly higher plant height $(109.6 \mathrm{~cm})$ over application of RDF alone. Application of FYM with RDF might have stimulated plant growth by improving seed germination, enhanced seedling growth and nutrient uptake compared to availability of nutrients through RDF alone.

Similar results were reported by Barik and Fulmali (2011). Among sub treatments and the highest plant height $(115.7 \mathrm{~cm})$ was found in $\mathrm{S}_{3}$ i.e. $30 \mathrm{~kg} \mathrm{~S}^{-1}$ and it was significantly superior over $\mathrm{S}_{2}$ i.e. $20 \mathrm{~kg} \mathrm{~S}^{-1}(109.4 \mathrm{~cm})$ and $\mathrm{S}_{1}$ i.e. $10 \mathrm{~kg} \mathrm{~S} \mathrm{ha}^{-1}(104.0 \mathrm{~cm})$ at harvest. Increase in plant height with increasing sulphur level might be resulted from synthesis of sulphur containing amino acids, proteins and activity of proteolytic enzymes. Similar results were obtained by Pavani et al., (2013).

\section{Dry matter production}

Data on dry matter production was found to be maximum (17.8 $\left.\mathrm{g}_{\text {plant }}{ }^{-1}\right)$ with $\mathrm{M}_{2}$ i.e. application of RDF along with $25 \% \mathrm{~N}$ through FYM when compared to application of RDF alone (14.4 g plant ${ }^{-1}$ ). Higher dry matter production with organic and inorganic sources could be attributed to enhanced assimilatory surface area which helped in the development of efficient photosynthetic system with better availability of nutrients and moisture produced higher dry matter. 
Table.1 Effect of sulphur levels and farmyard manure on growth and yield of sesame (Sesamum indicum L.)

\begin{tabular}{|c|c|c|c|c|c|c|c|c|}
\hline Treatments & $\begin{array}{c}\text { Plant } \\
\text { height } \\
(\mathrm{cm})\end{array}$ & $\begin{array}{c}\text { Dry } \\
\text { matter } \\
\text { Production } \\
\left(\text { g plant }^{-1}\right)\end{array}$ & $\begin{array}{c}\text { No. of } \\
\text { branche } \\
\text { s plant }^{-1}\end{array}$ & $\begin{array}{c}\text { No. of } \\
\text { capsules } \\
\text { plant }^{-1}\end{array}$ & $\begin{array}{c}\text { No. of } \\
\text { seeds } \\
\text { capsule }^{-1}\end{array}$ & $\begin{array}{c}1000 \text { seed } \\
\text { weight } \\
\text { (g) }\end{array}$ & $\begin{array}{c}\text { Seed } \\
\text { yield } \\
\left(\mathrm{kg} \mathrm{ha}^{-1}\right)\end{array}$ & $\begin{array}{c}\text { Stover } \\
\text { yield (kg } \\
\left.\text { ha }^{-1}\right)\end{array}$ \\
\hline \multicolumn{9}{|l|}{ Main treatments } \\
\hline $\mathrm{M}_{1}: \mathrm{RDF}$ & 105.8 & 14.4 & 6.6 & 66.5 & 64.0 & 2.6 & 520 & 1091 \\
\hline $\mathrm{M}_{2}: \mathrm{RDF}+25 \% \mathrm{~N}$ through FYM & 109.6 & 17.8 & 8.5 & 72.8 & 70.0 & 2.7 & 631 & 1289 \\
\hline $\mathrm{SEm} \pm$ & 0.81 & 0.13 & 0.19 & 1.06 & 1.00 & 0.02 & 4.0 & 10.9 \\
\hline $\mathrm{CD}(\mathrm{P}=0.05)$ & 3.65 & 0.98 & 0.66 & 4.79 & 4.54 & NS & 12.5 & 49.00 \\
\hline \multicolumn{9}{|l|}{ Sub treatments (Sulphur levels) } \\
\hline $\mathrm{S}_{1}: 10 \mathrm{~kg} \mathrm{ha}^{-1}$ & 104.0 & 13.2 & 6.8 & 64.4 & 62.2 & 2.7 & 459 & 1010 \\
\hline $\mathrm{S}_{2}: 20 \mathrm{~kg} \mathrm{ha}^{-1}$ & 109.4 & 16.8 & 7.4 & 73.7 & 67.1 & 2.7 & 549 & 1156 \\
\hline $\mathrm{S}_{3}: 30 \mathrm{~kg} \mathrm{ha}^{-1}$ & 115.7 & 20.7 & 8.5 & 75.0 & 69.1 & 2.7 & 626 & 1283 \\
\hline $\mathrm{SEm} \pm$ & 1.53 & 0.85 & 0.18 & 0.43 & 0.7 & 0.02 & 12.0 & 14.0 \\
\hline $\mathrm{CD}(\mathrm{P}=0.05)$ & 4.72 & 2.85 & 0.56 & 1.35 & 2.08 & NS & 37.2 & 43.3 \\
\hline \multicolumn{9}{|c|}{ Sub treatment at same level of main treatment } \\
\hline $\mathrm{SEm} \pm$ & 2.17 & 0.15 & 0.25 & 0.62 & 0.95 & 0.04 & 17.0 & 19.8 \\
\hline $\mathrm{CD}(\mathrm{P}=0.05)$ & NS & NS & NS & NS & NS & NS & NS & NS \\
\hline \multicolumn{9}{|c|}{ Main treatment at same/different level of sub treatment } \\
\hline $\mathrm{SEm} \pm$ & 1.94 & 0.18 & 0.28 & 1.18 & 1.14 & 0.03 & 14.4 & 19.5 \\
\hline $\mathrm{CD}(\mathrm{P}=0.05)$ & NS & NS & NS & NS & NS & NS & NS & NS \\
\hline
\end{tabular}


These findings are in conformity with those of Patel and Puraji (2003). The data pertaining to number of branches plant $^{-1}$ of sesame was significantly influenced by main treatments and sub treatments at all crop growth stages. The data on number of branches plant ${ }^{-1}$ was found to be maximum (8.5) under $\mathrm{M}_{2}$ i.e. RDF along with $25 \% \mathrm{~N}$ through FYM when compared to sole application of RDF (6.6). Highest number of branches plant ${ }^{-1}$ was observed (8.5) in $\mathrm{S}_{3}$ i.e. application of $30 \mathrm{~kg} \mathrm{~S}$ $\mathrm{ha}^{-1}$ treatment which was significantly superior over $S_{1}$ i.e. $10 \mathrm{~kg} \mathrm{~S} \mathrm{ha-1} \mathrm{(6.8)} \mathrm{and}$ $\mathrm{S}_{2}$ i.e. $20 \mathrm{~kg} \mathrm{~S} \mathrm{ha}^{-1}$ (7.4) (Table 1).

\section{Number of branches plnat ${ }^{-1}$}

The data pertaining to number of branches plant $^{-1}$ of sesame was significantly influenced by main treatments and sub treatments at all crop growth stages. The data on number of branches plant ${ }^{-1}$ was found to be maximum (8.5) under $\mathrm{M}_{2}$ i.e. $\mathrm{RDF}$ along with $25 \% \mathrm{~N}$ through FYM when compared to sole application of RDF (6.6). Highest number of branches plant ${ }^{-1}$ was observed (8.5) in $\mathrm{S}_{3}$ i.e. application of $30 \mathrm{~kg} \mathrm{~S}$ ha $^{-1}$ treatment which was significantly superior over $\mathrm{S}_{1}$ i.e. $10 \mathrm{~kg} \mathrm{~S}$ ha $^{-1}$ (6.8) and $\mathrm{S}_{2}$ i.e. $20 \mathrm{~kg} \mathrm{~S}$ ha $^{-1}$ (7.4).

\section{Number of capsules plant ${ }^{-1}$}

Number of capsules plant ${ }^{-1}$ indicated that application of RDF along with $25 \% \mathrm{~N}$ through FYM recorded higher number of capsules plant $^{-1}$ over application RDF alone. Higher number of capsules plant $^{-1}$ with application of RDF along with $25 \% \mathrm{~N}$ through FYM may be attributed to availability of macro and micro nutrients and improve favourable conditions for plant growth which ultimately resulted in higher yield. These results were corroborated with Yadav et al., (2009). Among sub plot treatments, the treatment fertilized with $30 \mathrm{~kg} \mathrm{~S} \mathrm{ha}^{-1}\left(\mathrm{~S}_{3}\right)$ had produced the highest number of capsules plant $^{-1}$ (75.0) significantly superior over other treatments fertilized with $\mathrm{S}_{2}$ i.e. $20 \mathrm{~kg} \mathrm{~S} \mathrm{ha}{ }^{-1}$ (73.7) and $\mathrm{S}_{1}$ i.e. $10 \mathrm{~kg} \mathrm{~S}^{-1}$ (64.4). Similar results were reported by Nagavani et al., (2001).

\section{Number of seeds capsule ${ }^{-1}$}

The treatment $\mathrm{M}_{2}$ (RDF along with $25 \% \mathrm{~N}$ through FYM) recorded higher number of seeds capsule ${ }^{-1}$ (70.0) over application of RDF (64.0) alone. It was clearly indicated that there is a need for adding organic manures to the soil in conjunctive with inorganic fertilizers, which increased the availability of nutrients considerably resulting in positive effect on growth parameters. These results agreed with the findings of Babalad (1999). Among sub treatments $\mathrm{S}_{3}$ i.e. application of $30 \mathrm{~kg} \mathrm{~S} \mathrm{ha}^{-1}$ has recorded significantly higher number of seeds capsules ${ }^{-1}(69.1)$ and it is significantly superior over $\mathrm{S}_{2}$ i.e. application of $20 \mathrm{~kg} \mathrm{Sha}^{-1}(67.1)$ and $\mathrm{S}_{1}$ i.e. application of $10 \mathrm{~kg} \mathrm{~S} \mathrm{ha}{ }^{-1}$ (62.2). From above findings, yield attributing characters were greatly affected by increasing sulphur application up to certain level. The similar findings were also reported by Chaubey et al., (2000). Interaction effect of number of seeds capsule ${ }^{-1}$ of sesame crop as influenced by main and sub treatments were non-significant. 1000 seed weight of sesame found non-significant with both main as well as sub treatments. The interaction affect was also found nonsignificant.

\section{Yield (kg ha-1)}

Seed and stover yield revealed that application of RDF along with $25 \% \mathrm{~N}$ through FYM recorded significantly higher seed yield (631 kg ha ${ }^{-1}$ ) and stover yield (1175 kg ha ${ }^{-1}$ ) over application of RDF alone. Higher seed yield and stover yield of sesame was obtained with RDF along with $25 \% \mathrm{~N}$ through FYM significantly improved soil 
physico-chemical characters via modifying the soil environment, for sustained nutrient supply, better aeration and microbial activity influencing nutrient uptake and improving growth and yield components and ultimately yield of sesame. The results are in line with Maheshbabu et al., (2008). Within the sub plots, the seed yield $\left(626 \mathrm{~kg} \mathrm{ha}^{-1}\right)$ and stover yield $\left(1283 \mathrm{~kg} \mathrm{ha}^{-1}\right)$ of sesame was significantly higher with $\mathrm{S}_{3}$ (fertilized with 30 $\mathrm{kg} \mathrm{S} \mathrm{ha}^{-1}$ ) followed by $\mathrm{S}_{2}$ i.e. $20 \mathrm{~kg} \mathrm{~S} \mathrm{ha}^{-1}(549$ $\mathrm{kg} \mathrm{ha}{ }^{-1}$ seed yield and $1152 \mathrm{~kg} \mathrm{ha}^{-1}$ stover yield). The seed yield (459 kg ha ${ }^{-1}$ ) and stover yield $\left(1010 \mathrm{~kg} \mathrm{ha}^{-1}\right)$ of sesame crop with $\mathrm{S}_{1}$ i.e. $10 \mathrm{~kg} \mathrm{~S} \mathrm{ha}{ }^{-1}$ was found to be lower. Cumulative influence of $S$ application maintained balance source-sink relationship and ultimately resulted in increased seed yield and stover yield of sesame. The results were in close conformity with the findings of Ganeshmurthy (1996) and Hussain et al., (2011). Interaction effect of seed yield and stover yield of sesame crop as influenced by main and sub treatments was found to be nonsignificant.

From the present investigation, it can be concluded that application of RDF (40-60-40 $\mathrm{kg} \mathrm{N} \mathrm{P} \mathrm{K} \mathrm{ha}{ }^{-1}$ ) along with $25 \% \mathrm{~N}$ through FYM for sesame crop was ideal for obtaining higher growth, yield attributes and yield. Among different levels of sulphur, application of sulphur@30 kg ha ${ }^{-1}$ was found ideal for sesame in order to obtain higher growth, yield attributes and yield.

\section{References}

Alloway, B.J., 2008. Micronutrient deficiencies in global crop production. Business media, 2(2): 12- 17.

Annals of Agricultural Research, 30 (1 and 2): $53-58$.

Babalad, H. B., 1999. Integrated nutrient management for sustainable production in soybean based cropping system.
Ph.D. Thesis, University of Agricultural Sciences, Dharwad.

Barik, A. K., and Fulmali, J. 2011. Effect of integrated plant nutrient supply through organic and mineral sources on productivity of summer sesame. Journal of Oilseeds Research, 28 (2): 120- 122.

Chatterjee, C., and Nautiyal N. 2000. Developmental aberrations in seed of boron deficient sunflower and recovery. Journal of Plant Nutrition, 23: 835841.

Chaubey, A. K., Singhand, S. B and Kaushik, M. K. 2000. Response of groundnut (Arachishypogaea) to sourse and level of sulphur fertilizer in mid-western plains of Uttar Pradesh. Indian Journal of Agronomy, 45 (1): 166- 169.

Hussain, K., Islam, M., Siddique, M. T., Hayat, R and Mohsan, S. 2011. Soybean growth and nitrogen fixation as affected by sulphur fertilization and inoculation under rainfed conditions in Pakistan. International Journal of Agriculture and Biology, 13 (6): 951-955.

Maheshbabu, H. M., Hunje, R., Biradar Patel, N. K and Babalad, H.B. 2008. Effect of organic manures on plant growth, seed yield and quality of soybean. Karnataka Journal of Agricultural Sciences, 21 (2): 219-221.

Nagavani, A. V., Sumathi, V., Chandrika, V and Muneendrababu, A. 2010. Effect of nitrogen and sulphur on yield and oil content of sesame (Sesamumindicum L.). Journal of Oilseeds Research, 18 (1): 73- 74.

Patel, S. M., and Puraji, B. T. 2003. Effect of organic measures and fertilizer levels on growth, yield parameters and yield of irrigated soybean. National Seminar on Stress Management in Oil seeds for attaining self-reliance in edible oils.

Pavani, S., Bhanu rekha, K., Sudhakarababu, S. N and Madhu, M. 2013. Effect of nitrogen and sulphur on growth, yield 
and quality of sunflower (Helianthus annuus L.). Crop Research, 45 (1, 2 \& 3): $152-153$.

Poonia, K. L., 2000. Effect of planting geometry, nitrogen and sulfur on growth and yield of sunflower (Helianthus annuusL.). Journal of Eco-Physiology, 3: $59-71$.
Scherer, H.W., 2001. Sulphur in crop production. European Journal of Agronomy, 14: 81- 111.

Yadav, R. A., Tripathi, A. K and Yadav, A. K. 2009. Effect of micronutrients in combinations with organic manures on production and net returns of sesame (Sesame indicum L.).

\section{How to cite this article:}

Mamatha, K., G.E.Ch. Vidya Sagar, P. Laxmi Narayana and Padmaja, G. 2017. Effect of Sulphur Fertilization in Combinition of Farmyard Manure on Sesame (Sesamum indicum L.). Int.J.Curr.Microbiol.App.Sci. 6(9): 3679-3684. doi: https://doi.org/10.20546/ijcmas.2017.609.453 